\title{
HUGH CUNNINGHAM
}

\section{The reputation of \\ philanthropy since 1750 \\ Britain and beyond}

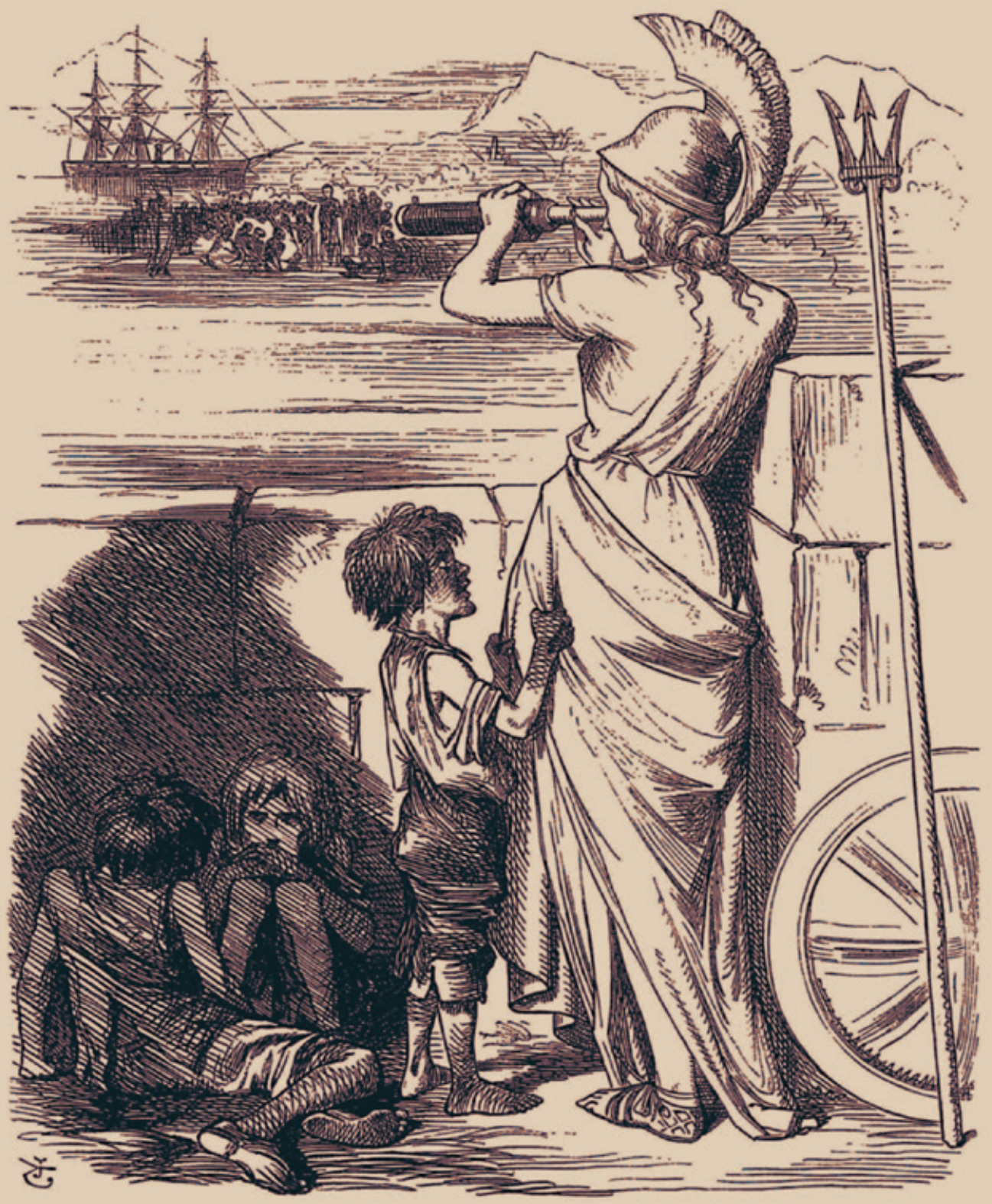




\section{The reputation of philanthropy since 1750}

\section{MANCHESTER 1824}

Manchester University Press 
Hugh Cunningham - 9781526146397 Downloaded from manchesterhive.com at 04/26/2023 01:36:47PM via free access 


\title{
THE REPUTATION OF PHILANTHROPY SINCE 1750 Britain and beyond
}

\author{
Hugh Cunningham
}

Manchester University Press 
Copyright (C) Hugh Cunningham 2020

The right of Hugh Cunningham to be identified as the author of this work has been asserted by him in accordance with the Copyright, Designs and Patents Act 1988.

Published by Manchester University Press

Altrincham Street, Manchester M1 7JA

www.manchesteruniversitypress.co.uk

British Library Cataloguing-in-Publication Data

A catalogue record for this book is available from the British Library

ISBN 9781526146380 hardback

First published 2020

The publisher has no responsibility for the persistence or accuracy of URLs for any external or third-party internet websites referred to in this book, and does not guarantee that any content on such websites is, or will remain, accurate or appropriate.

Cover image: 'Telescopic Philanthropy', Punch, 44 Mar. 1865

Typeset by Newgen Publishing UK 